Relations industrielles

Industrial Relations

\title{
Labour Law Through the Prism of Paccar
}

\section{A.W.R. Carrothers}

Volume 45, numéro 3, 1990

URI : https://id.erudit.org/iderudit/050610ar

DOI : https://doi.org/10.7202/050610ar

Aller au sommaire du numéro

Éditeur(s)

Département des relations industrielles de l'Université Laval

ISSN

0034-379X (imprimé)

1703-8138 (numérique)

Découvrir la revue

Citer cet article

Carrothers, A. (1990). Labour Law Through the Prism of Paccar. Relations industrielles / Industrial Relations, 45(3), 585-611.

https://doi.org/10.7202/050610ar
Résumé de l'article

Labour Law Through the Prism of Paccar
Tous droits réservés (c) Département des relations industrielles de l'Université Laval, 1990
Ce document est protégé par la loi sur le droit d'auteur. L’utilisation des services d'Érudit (y compris la reproduction) est assujettie à sa politique d'utilisation que vous pouvez consulter en ligne.

https://apropos.erudit.org/fr/usagers/politique-dutilisation/ 


\title{
Labour Law Through the Prism of Paccar
}

\author{
A.W.R. Carrothers
}

This is a story about accidents of litigation. When people contend for control over principles, personality, identity, possessions, freedoms, power - it is not exceptional that they should seek resolution through «third party intervention »: a friend, a priest - even the legal system. It is inevitable that the process of intervention generates «spin-offs» which the contestants did not seek or want, but which nevertheless take on a life of their own. Such is the case with Paccar ${ }^{1}$. The litigants wanted to know from the Labour Relations Board of British Columbia whether the employer could make unilateral changes to terms and conditions of employment after the collective agreement expired but before the employer recovered the right to lock out.

It is doubtful that they wanted to know whether a collective agreement is a contract, or whether the relationship between an employer and an employee is one of status, or about the significance of the declaration of purposes and objects in the British Columbia Labour Code, or the balancing of rights, duties and powers in the Code, or the deference of the courts to decisions of staturory tribunals, or the right of the Labor Board to appear before the courts - let alone did they want to know about the contention between the ground rules in the Labour Code for a regulated system of collective bargaining and the traditions of the private law, whatever they may be. It is even more doubtful that the litigants set out to obtain the views of the Supreme Court of Canada on these arcane questions.

Yet that is what they bought. And that is what Paccar is about. These issues are the accidents - the incidents - of this litigation. And that is what I have set out to explore.

I tender a caveat. This article is broader than it is deep. Its object is to catch and record the spin-offs, or, to use the metaphor of the title, to identify variegations in labour law as revealed through the special prism of $\mathrm{Pac}$ car, and through them to challenge some conventional assumptions which I think trapped a number of the judiciary. It is a topographical reflection, a claim only to surface rights to thoughts and ideas. The wells of judicial authority are available to the serious student through treatises and scholarly articles on Canadian labour law and industrial relations, and through their original sources - decisions of statutory tribunals and judgments of the courts - all accessible to the touch of a computer.

* Carrothers, A.W.R., Professor of Law Emeritus, University of Ottawa.

Relat. ind., vol. 45, no 3, 1990 (C) PUL ISSN 0034-379 X 


\section{PROLOGUE: SOME GROUND RULES OF COLLECTIVE BARGAINING}

The first «Canadian» policy ${ }^{2}$ regulating the operation of labourmanagement relations appeared in the reign of Edward VII. It was the policy of postponing strikes until the federal Department of Labour had an opportunity to send in a conciliator - what today would probably be called a disputes settlement officer - to attempt to induce a settlement without stoppage of work. It is the basic strategy of government intervention in Canada, in the name of the public interest, in legislative regulation of labour-management conflict, and is endemic in Canada today. It is at the root of the strongest hands-on labour policy in the industrialized democratic world, and is very much part of the Paccar problem.

There are four stages in the establishment and operation of collective bargaining at which employees and their union are particularly vulnerable to unfriendly behaviour from employers. The first is at the stage of organizing employees into a union. The natural inclination of most employers is to discourage organization by taking hostile action against employees who are or are suspected of taking part in the organizing. The second occurs when the union, believing it to have organized a majority of the employees, applies to the labour relations board for a certificate of exclusive bargaining authority. The employer may seek to change terms of employment, either favourably or unfavourably, to discourage employee support of the union and thereby to seek to establish a base for challenging the union's claim to majority support. The third occurs at the stage of negotiating a first collective agreement where the prospect of impasse and breakdown in the collective bargaining process is likely to be at its highest. The fourth stage is at the renegotiation of a collective agreement whose term is expiring or has expired.

The Canadian pattern of managing these sensitive moments is as follows. To address the first, organizational, stage the legislation declares a right in employees to join a union of their choice and to declare it to be an unfair labour practice for an employer to interfere with that right, jurisdiction being in the labour relations board to police the prohibition. At the second stage the statute obliges the employer to freeze terms and conditions of employment while the application for certification is pending. For the third stage the freeze is continued, and some jurisdictions provide for «first agreement» arbitration at the point of impasse on the application of either party (see later for a consideration of «fictitious dualities» in the labour codes).

For the fourth stage every jurisdiction in Canada, except British Columbia, declares a statutory freeze on terms and conditions of employment from the time when the term of the collective agreement runs out until the parties acquire the right to strike and to lock out ${ }^{3}$. At that point there is systemic change in the policy of «postponing strikes»: the parties are released from the freeze, subject to a continuing duty to bargain in good faith. That duty features throughout this essay.

There has been much uncertainty as to what terms of employment actually apply to the work place during this latter freeze. That question is 
also addressed in this essay. There is a growing practice for the parties to a collective agreement, particularly where there is a mature relationship between management and the union, to agree to a «bridge clause», or «bridging agreement», that continues the terms of the expired agreement from termination to renewal, or impasse and the recoupment of the right to strike or lock out.

The British Columbia Labour Code followed the Canadian pattern (it was also an innovator in facilitating first agreement arbitration ${ }^{4}$ ) down to the fourth sensitive stage, where it was silent on the matter of a freeze. Further, in Paccar there was a bridging clause in the expired collective agreement, but it fell well short of addressing the issue of continuing the terms of the collective agreement during the interregnum between the termination of the collective agreement and the recoupment of the right to invoke economic sanctions, assuming impasse.

The industrial relations issue (that is, the policy issue) in Paccar is whether the employer should be released from the policy of preventing unilateral change at the time of impasse in negotiations before the union has been released from the prohibition against the right to strike, or whether unilateral change should be postponed to the point where recourse to economic sanctions is reciprocal.

The issue before the Board was whether, simply put, the statute having spoken to the matter of the freeze (or a related remedy) on certain occasions, the silence of the legislature should be taken as meaning that it did not intend the ban to run during the period in question. Did the legislature choose not to speak directly in the matter, or did it fail to speak at all?

The issue before the Supreme Court of Canada, as it should have been before the British Columbia Supreme Court and the British Columbia Court of Appeal, related to the matter of judicial review of a decision of a statutory tribunal in the presence of a «state-of-the-art) privative clause: was the decision of the Board «patently unreasonable» and therefore not protected by the policy of «curial deference» to the judgment of a specialized quasi-judicial statutory tribunal?

\section{THE FACTS AND THEIR VOYAGE OF DISCOVERY THROUGH THE BOARD AND THE COURTS}

This recitation of the facts is intended to cover the essentials of the circumstances giving rise to the legal issues. The legal narrative is not intended at this stage to probe in depth the issues of law; it is intended to position the reader for a critical examination of the issues of (1) the nature of the collective agreement and the statutory interrelation of the employer, the union and the employee; (2) the legal status of the employee under modern collective bargaining legislation; (3) uses and usefulness of the declared purposes and objects of the labour code(s); (4) the artifices of dualities in Canadian labour codes; and (5) the nature and application of the standard of reasonableness in construing the codes: the privative clause and the nature and scope of judicial review. 
Paccar was engaged in manufacturing trucks. CAIMAW ${ }^{5}$ was certified for a bargaining unit of some 350 employees and had a collective agreement with the employer covering the period 1 May 1980 to 30 April 1983. During its term the employer laid off employees and restricted the scope of its operations. At the time of the first hearing by a three-person panel of the British Columbia Labour Relations Board only ten persons were employed in the warehouse operation. The economic condition of the enterprise doubtless prompted the employer to seek extensive changes to the collective agreement that related to the radically reduced bargaining unit.

The collective agreement contained a clause that provided for the continuation of the collective agreement after its term expired unless either party gave notice otherwise. This clause reflected the contents of the Labour Code. It also provided for the continuation of the collective agreement during negotiations, «it being agreed that negotiations shall be discontinued upon delivery of written notice by either Party». (The question was not raised whether that provision was contrary to the parties' duty to continue to bargain in good faith so long as the union was certified as the exclusive bargaining authority for the employees in the unit: as will be seen, the employer in fact continued to treat with the union as distinguished from treating with individual employees.)

The employer accordingly gave to the union notice to terminate and to commence negotiations for a new collective agreement, and presented proposals amounting to a complete revision of the collective agreement. Two months later the employer gave notice to terminate the terms of the expired collective agreement except as stipulated in the notice.

The union applied to the Board for a determination whether a collective agreement was in force and, if not, whether the employer was entitled to alter unilaterally the terms and conditions of employment. The panel of the Board decided that a collective agreement was not in force and that the employer could make changes unilaterally, subject to the employer's duty to bargain in good faith and to recognize the union's right to act exclusively as the bargaining authority for the employees. I find the following passage in its decision instructive:

We conclude that the employer and the trade union may unilaterally impose terms and conditions of employment to be 'incorporated' into the individual contracts of employment which spring up on the termination of the collective agreement. The appropriate response by the employer or the trade union to unacceptable new terms proposed by the other is to lock out or strike ${ }^{6}$.

The union applied to the Board for a reconsideration of the decision.

I now turn to the facts in Hydro, which for a while became a companion to Paccar. The following statement is taken from the decision of the second panel of the Board.

We now propose to review the factual backgrounds to the B.C. Hydro award and the Paccar decision, as well as the conclusions reached on those facts.

First of all, we summarize the facts from the B.C. Hydro award. The parties in this matter, or their predecessors, have had a collective bargaining relationship for 
approximately thirty years. During this time, they have negotiated upwards of seventeen collective agreements. Notwithstanding the absence of a «bridge clause», when there has been a hiatus between agreements, the practice of the parties has been to govern themselves according to the terms and conditions of the most recently expired collective agreement.

This practice changed with the expiry of the 1981-83 collective agreement. On March 18 1983, about two weeks prior to the expiry of the 1981-83 collective agreement, B.C. Hydro wrote to the IBEW in the following terms:

As a result of the recent Labour Relations Board decision dated 14 February 1983 regarding backhoe contractors under contract with B.C. Hydro, there exists the possibility of their being included in the IBEW bargaining unit. In the event they consent to representation by the IBEW and are included in the bargaining unit, we will be faced with the task of having to negotiate terms and conditions of their 'employment'.

B.C. Hydro is very concerned at the possible impact of the inclusion of the dependent backhoe contractors into the bargaining unit. We regard the right, and indeed obligation, to contract out work as being vitally important. Please take note that it is our position that even in the event dependent backhoe contractors are included in the bargaining unit, they are not covered by the current Collective Agreement. The terms applying to the dependent backhoe contractors, if included in the IBEW 213 certification, will only be those terms negotiated between the Parties?.

For the record, given the possibility of a significant change to the bargaining unit structure and thus the basis from which the current Collective Agreement was negotiated, we feel compelled to take the following measures upon expiry of the current Collective Agreement [...]

Except as noted above, the present terms and conditions as set out in the Collective Agreement will continue beyond the expiry date for present employees (but excluding dependent backhoe contractors and their employees) until further notice.

The union disagreed.

The 1981-83 collective agreement expired without a new agreement having been reached. In fact, negotiations for a renewal agreement did not start until some weeks following the expiry date. Hydro made changes according to its notice, and grievances were filed.

The merits of the grievances were subsequently settled, but the parties asked the arbitration board ${ }^{8}$ to deal with the issue of whether B.C. Hydro was entitled to make the unilateral alterations to employment conditions that it did having regard to all the circumstances of the case ${ }^{9}$.

\section{Arbitrator Munroe noted that}

McGavin ${ }^{10}$ appeared to cast doubt on the continuing vitality of the notion of individual contracts of employment in the face of a regime of collective bargaining ${ }^{11}$.

However, he limited McGavin to its facts - a collective agreement was in operation - and concluded that where the collective agreement was terminated its essentials were incorporated into revived individual employment contracts. Further, as a matter of statute interpretation Munroe concluded that the employer acquired the right to make unilateral changes prior to acquiring the right to lock out, subject to the continuing statutory duty to bargain in good faith. 
The union applied to the Labour Relations Board to set aside the decision of the arbitration board.

The Hydro and Paccar applications were consolidated for decision purposes under the issue

whether an employer, after the expiry of the collective agreement between it and the trade union representing its employees, is entitled to alter unilaterally the terms and conditions of employment of its employees.

The consolidated applications were heard by a panel of the Board consisting of the chairman and the four vice-chairmen. Following a review of McGavin, the Board's decision reads:

it is no longer appropriate to speak of individual contracts of employment and common law principles flowing therefrom in respect of an employer-employee relationship which is governed by the Labour Code [...] We are of the view that the comments of Chief Justice Laskin concerning the inapplicability of individual contracts of employment and the common law apply regardless of whether a collective agreement is in force ${ }^{12}$.

The Board concluded that section 46(a) of the Labour Code, conferring exclusive bargaining authority on the union, did not prevent an employer from making

unilateral alterations to terms and conditions of employment, subject to his duty and obligations $[. .$.$] to bargain in good faith and make every reasonable effort to con-$ clude a collective agreement or a renewal or revision of it ${ }^{13}$.

The Board noted that Hydro made unilateral changes before negotiations began, but agreed with the ultimate conclusion of the first Paccar panel and the board of arbitration in Hydro that the employer recovers the right to make unilateral changes in the circumstances stipulated in the statement of the issue.

The two unions then petitioned the British Columbia Supreme Court for an order quashing the decision of the review panel. Mr. Justice Meredith found that

counsel for the employers and the unions agree with me that at law, labour or otherwise, the employers in these cases have no authority to make unilateral alteration in terms and conditions of employment at any time ${ }^{14}$.

Mr. Justice Meredith ordered that the matter be remitted to the Labour Relations Board for further consideration.

The employers appealed that order to the British Columbia Court of Appeal, but Hydro and IBEW withdrew before the appeal was heard, leaving as protagonists Paccar and CAIMAW.

The appeal was heard by a bench of five members of the British Columbia Court of Appeal ${ }^{15}$. Mr. Justice Seaton wrote the judgment for the Court, dismissing the appeal. I present the following three exerpts as conveying the essence of the judgment (it is considered at length below): 
- The law of contracts underlies the whole collective bargaining process. Unions and employers enter into agreements that have all of the elements of common law contracts ${ }^{16}$.

- Variation of an existing contract by one party requires the consent of the other, and nothing in the Labour Code supports a different conclusion respecting a collective agreement ${ }^{17}$.

- [...] after the expiry of a collective agreement the implied terms and conditions of employment are those found in the expired agreement ${ }^{18}$.

The decision was appealed to the Supreme Court of Canada. The appeal was allowed. The six person court divided four to two ${ }^{19}$. The most comprehensive judgment was written by Mr. Justice La Forest, concurred in by the Chief Justice.

The judgment focuses at the outset on the narrow issue of judicial review: whether the decision of the second panel of the Labour Board amounted to a patently unreasonable error of law and therefore should be quashed. The judgment may be summarized as follows:

- His lordship concluded that «the result reached by the Board is as reasonable as the alternative ${ }^{20}$ 》 and that the British Columbia Court of Appeal erred in substituting its view of the appropriate result on the point of law and policy for the judgment of the Board.

- Citing McGavin, and concluding that the observations in it respecting the relationship between the employer and the individual employee to be one of general application within the framework of the collective bargaining legislation, his lordship stated: "The scheme of the Labour Code [...] does not leave any room for the operation of common law principles ${ }^{21}$ ».

- In appropriate circumstances the terms and conditions of employment in the expired collective agreement are presumed to govern the relationship between the employer and the individual employee. that:

Mr. Justice Sopinka, for himself and Mr. Justice Lamer, concluded

- [...] the Board's decision is consistent with the contractual expectations [...] nor was the employer bound by any ordinary contract ${ }^{22}$.

- The Labour Code, notwithstanding the use of the word, is not a code in the true civil law sense. It does not purport to totally exclude the general law. Accordingly, in respect of some matters, it is silent. This lacuna cannot be filled by any amount of liberal construction short of out-and-out judicial legislation. Rather, the general law applies to fill the void. In common law jurisdictions, this is the common law ${ }^{23}$.

- The effect of the Board's decision is that, while the springing up of individual contracts of employment on the expiry of the collective agreement would be inconsistent with the statutory scheme of collective bargaining, the right of the employer to change the terms and conditions of employment in the absence of any agreement, collective or otherwise, is not. This result conforms with the principles referred to above and is the correct result. It is, therefore, not necessary to consider whether the decision was reasonable, or much less, patently unreasonable ${ }^{24}$. 
Madam Justice Wilson's dissent is in essence an appraisal of the Board's decision, leading to the conclusion that the decision was patently unreasonable as against the legislated purposes and objects of the Labour Code. The following quotations relate:

- I do not see how an employer can be bargaining in good faith towards a new collective agreement while at the same time unilaterally imposing detrimental terms upon the employees which he knows have already been rejected ${ }^{25}$.

- Compromise, which is the accepted means of ensuring the ongoing nature of the good faith bargaining process, is thus declared by the employer to be at an end $[\ldots]^{26}$.

- Why, one might ask, should an employer be able to destroy in this way the freedom and equality of bargaining power both parties must have at the bargaining table? Why should he have this new power ${ }^{27}$ ?

- This new power creates instability ${ }^{28}$.

- Nothing in the Code, they say, prevents the employer from unilaterally imposing new terms. Or do we in filling the legislative vacuum take guidance from the legislative scheme ${ }^{29}$ ?

- The continuance of the terms and conditions in the expired collective agreement from impasse to the acquisition of the right to strike and lock out 'does not interfere with the balance of bargaining power ${ }^{30}$.

The judgment of Madam Justice L'Heureux-Dubé is the longer of the two dissents, but its essentials leading to the conclusion that the decision of the Board was patently unreasonable may be summarized briefly.

- The Board ignored section 27 of the Labour Code, being the legislative statement of purposes and objects; there is no reference to the section in the decision and it cannot be presumed that the Board implicitly considered the provision in it respecting the public interest or the development of effective labour relations $s^{31}$.

- The decision of the Board amounted to a declaration of a «mini-Code» akin to new legislation ${ }^{32}$.

- The decision is inconsistent with the principles that sustain the statutory scheme of collective bargaining, including freedoms of the participants and the balance of bargaining power ${ }^{33}$.

- The Board failed to reject the policy solution contrary to the fundamental objectives of the Act ${ }^{34}$.

- The conclusion of a collective agreement, to use the Board's language, may also 'lead to a complete sterilization of the capacity to make non-negotiated alterations; yet, that is not an undesirable situation ${ }^{35}$.

THE NATURE OF THE COLLECTIVE AGREEMENT AND THE STATUTORY INTERRELATION OF THE EMPLOYER, THE UNION AND THE EMPLOYEE

Four statements in the single judgment of the British Columbia Court of Appeal relate: 
the law of contract underlies the whole collective bargaining law process ${ }^{36}$; collective agreements have all the elements of common law contracts ${ }^{37}$; a collective agreement is a contract ${ }^{38}$; basic contract law is equally applicable to a collective agreement ${ }^{39}$.

I read these statements as referring both to the formation of a collective agreement and to its operation and administration.

In fact the English courts, from the time the issue first arose, recognized the collective agreement only insofar as it was incorporated into the contract of employment ${ }^{40}$. Early Canadian cases took a similar approach ${ }^{41}$. What gave the collective agreement juridical significance was the collective bargaining legislation.

At the threshold of the formation of the collective agreement the statute could not be more at odds with the common law. I refer to the statutory duty to bargain in good faith and make every reasonable effort to make a collective agreement. There is no duty to bargain in the common law of contract. The norm of good faith in contract formation is, basically, indistinguishable from the good faith that sustains human relationships at large, within or without the law. The good faith requirement in the statute is tied into making "every reasonable effort», and has led to a substantial jurisprudence distinguishing «hard bargaining», which is permissible, from "surface bargaining», which is an unfair labour practice ${ }^{42}$. (The U.S. law is even more complicated, distinguishing between mandatory and permissible subjects for collective bargaining ${ }^{43}$.) There is no such distinction at common law. How can the common law of contract formation possibly relate?

As to the operation and administration of the collective agreement, the labour codes require that the collective agreement contain a clause providing for binding arbitration of grievances, which may be individual or policy grievances (the preliminary issue heard by Arbitrator Munroe in Hydro was a policy grievance). The statutory prescription gives boards and arbitrators considerable latitude in designing remedies ${ }^{44}$ unheard of at common law or in equity ${ }^{45}$. Reinstatement for wrongful dismissal is a common remedy under a collective agreement. No court of equity would order specific performance of a contract of personal service. Other common arbitral remedies include progressive discipline, suspension, reprimand, ordering a change in the employer's personnel records, ordering an employer to deliver a letter of recommendation, ordering medical treatment (e.g. for alcohol addiction) as a condition of reinstatement, and attaching significance to an apology or lack of apology from a miscreant employee. The Board itself is empowered by the statute to issue cease orders and mandatory orders, such as to stop striking and return to work: the power does not bear comparison with the limited scope of equitable remedies ${ }^{46}$.

The labour codes prescribe a minimum duration of a collective agreement and on whom it is binding, and prohibit strikes and lockouts during its term; they also preserve the status of employee where a person is on strike: where are the common law roots for that? 
The common law of contract is based on mutuality of freedom of contract. The statute law of collective bargaining protects the right of the trade union, fundamental to the statutory scheme of collective bargaining, to oblige the employer to come to the bargaining table for the purpose of entering into a collective agreement. How can the common law of contract relate to that?

The substantive law of contract also turns out to be irrelevant to the operation of the collective agreement. McGavin specifically rejects the relevance of repudiation and fundamental breach ${ }^{47}$. A strike at common law in the last century was a collective refusal to perform a contract of employment: conspiracy to commit a fundamental breach ${ }^{48}$.

Problems of oral contracts do not arise: the labour codes require that a collective agreement be reduced to writing. Problems of correspondence reliance on the mails - rarely arise: physical presence of representatives of the parties at the bargaining table - eye to eye contact - is still a reality. The doctrine of consideration (or the concept of cause in civil law) and the significance of the seal are meaningless, as is the Statute of Frauds and its heavy overlay of judicial recreation. The use of letters of understanding in the administration of the collective agreement obviates the need for the common law of variation, with its complicating stipulation for consideration. The present position on the question of rectification appears to be that it may be proscribed by the prohibition against an arbitrator's changing the terms of a collective agreement unless the parties bargain to confer that jurisdiction upon him $^{49}$.

All that is left of the substantive common law of contract is the element of mutuality of intent. But there are many agreements that are not contracts at common law. Social arrangements are an obvious case. The bulk of family (domestic) relations is another. Even parties to a commercial arrangement can agree that it is not to be enforceable at common law ${ }^{50}$. The elements of bargain and agreement in collective bargaining do not need the slightest sustenance from the common law.

Finally, the fairly recent introduction (it preceded Paccar) of first agreement arbitration which, in circumstances prescribed by statute and administered in the discretion of the labour board, means that the first encounter may produce a collective agreement that cannot even be described as consensual ${ }^{51}$.

\section{THE STATUS RELATIONSHIPS}

As can be sensed from the previous section, the question of the interrelation of the employer, the union and the individual employee is closely related to the question of the nature of the collective agreement.

It is the thesis of this part of the article that the labour code prescribes the source of the power of trade unions to treat with the employer to the extent of precluding negotiations between the employer and the individual employee, and puts the union in control over the enforcement of the rights of the individual employee; that the resulting relationship between the 
employer and the employee is one of status imposed by statute, not one of contract; and that the relationship precludes the revivication of the individual contract of employment so long as the certification of the union and the employer's resulting statutory duty to bargain in good faith remains. The continuation of the terms of the collective agreement during the hiatus between the expiry of the agreement (barring supervening circumstances) and the acquisition of the right to strike and lock out is sustained by the status relationship. The terms adhere to that statutory status relationship, and the continuation does not need a contractual base.

Prior to McGavin, what Arbitrator Munroe calls the institutional consensus ${ }^{52}$ was that after termination of the collective agreement the individual contract of employment revives and the employer recovers his power to make unilateral changes consistent with his continuing duty to bargain in good faith. In McGavin the Supreme Court of Canada said that «individual relationships as between employer and employee have meaning only at the hiring stage ${ }^{53} . »$ But in fact the collective agreement was in operation at the relevant point in McGavin. Should McGavin be taken to apply to the interregnum or be confined to its facts?

Arbitrator Munroe in an earlier B.C. Hydro case ${ }^{54}$ observed that McGavin «appeared to cast doubt on the continuing vitality of the notion of individual contracts of employment in the face of a regime of collective bargaining». After reflecting on the point, Munroe then stated that:

most of the terms of the terminated collective agreement, including the grievance and arbitration provisions, are imported, upon such termination, into the revived individual employment contracts.

Munroe cites that decision in his B.C. Hydro decision that wound up in the British Columbia Court of Appeal in Paccar.

Mr. Justice Kelly in Telegram ${ }^{55}$ states:

I wish to give an explanation for the use of the expressions 'relationship of employer and employee' and 'terms and conditions of employment'. I do so to avoid the use of the phrase 'individual contract of employment'.

His lordship then puts the position as follows:

The accepted view appears to be that where, after the collective agreement has expired, the employee has continued to work for the employer and the employer has continued to accept the benefit of his services, there being no agreement to the contrary, and no other circumstances from which there may be implied terms and conditions of employment different from those set out in the collective agreement, the terms and conditions of the employment after expiry are to be implied and would be similar to those spelled out in the collective agreement which related directly to the individual employer-employee relationship ${ }^{56}$.

The concluding words are consistent with the notion of a statutory status relationship between the employer and the employee, although the test of «direct relevance» will likely require some probing ${ }^{57}$. 
The continuance of the terms of the expired collective agreement (subject to reservations about the scope of the terms) seems to receive general acceptance in the name of avoiding chaos ${ }^{58}$. Yet describing as chaotic the consequences of recognizing the employer's power of unilateral change in the interregnum to which this essay is directed appears hyperbolic ${ }^{59}$.

At the first Paccar hearing the Board decided that the employer had power to make unilateral change to the revived contracts of employment. The second time round counsel for the union accepted the notion of individual contracts of employment and argued that any change requires mutual consent ${ }^{60}$. The Board then rejected the notion of individual contracts of employment as being inconsistent with McGavin and rejected the relevance of the common law and decided that the employer could effect unilateral change upon impasse, subject to the continuing duty to bargain in good faith. That is the view that was sustained in the Supreme Court of Canada.

My conclusion is that, the individual employer-employee relationship of mutually having been limited in effect to the moment of hiring, and lacking any capacity to be revived in contractual form so long as the union certification remains, the continuing relationship between the employee and the employer cannot be contractual but must be one of status imposed by the Labour Code.

\section{THE PURPOSES AND OBJECTS OF THE LABOUR CODE: THEIR USE AND USEFULNESS}

It is quite unclear to me that relieving the employer from the freeze at the point of impasse, thereby giving it power unilaterally to change terms and conditions of employment in a way that is consistent with its duty to recognize the union as the certified bargaining authority and the employer's duty to bargain with it in good faith, before the union has acquired the statutory power to strike and the employer has acquired the "reciprocal» right to lock out (which in most cases is of little moment to the employer), is inconsistent with the preamble and the itemized «purposes and objects» of section $27(1)^{61}$.

There are sensitive moments at which provisions (declarations) of that nature can direct the philosophy of the legislation. In my view one of the most significant points marks a critical difference between Canadian and US collective bargaining laws. In the US the administrative agency is a neutral in the struggle between employers and unions. In Canada labour boards have resolved that the basic object of the labour codes is to advance the policy of collective bargaining ${ }^{62}$. That orientation is at its dramatic best in the board's use of its discretion in designing bargaining units to advance the viability and success of the collective bargaining process itself. The policy also affects the board's approach to unfair labour practices and the design of remedies ${ }^{63}$. These are strategic choices of first importance. But other policy statements do not make the choice of competing interests so clear. That is the case with section $27(1)$, which sets out a plurality of competing interests, including two evident and conflicting public interests 
relating to the operation of the collective bargaining system: the public interest in collective bargaining as public policy for the governance of relations between employers and the labour force in a mixed enterprise political economy; and the public interest (or the collectivity of private interests) in protecting innocent and powerless bystanders from harm flowing from the invocation of economic sanctions by the parties (identified in the preamble of section 27(1)), or in constraining through ad hoc legislation social, political or economic destabilization flowing from these sanctions.

The amendment to section 27(1) as noted in the dissent of Madam Justice L'Heureux-Dubé ${ }^{64}$ and enacted subsequent to the decision of the British Columbia Court of Appeal in Paccar verbalizes, for the exercise of the Board's (now Council's) discretion, the context of a "competitive market economy». This, I submit, strengthens the justification of the Board's decision that releases the employer on bargaining impasse to make changes that relate to the employer's competitiveness in the market in which it must function and survive.

Madam Justice L'Heureux-Dubé faults the Board for not addressing section $27(1)$ and its ramifications, and goes so far as to say that this «failure» was "fraught with consequence ${ }^{65}$ ». Is it reasonable to conclude that, because no reference was made to section $27(1)$, the panel of the Board, consisting of the chairman and four vice-chairmen, after having heard argument from top counsel of the labour bar of British Columbia on a rehearing of a sensitive issue, was not mindful of the legislated purposes and objects of the Labour Code?

When to enter upon a teleological discourse, or hold hearings with a view to formulating "general guidelines to further the operation of this Act ${ }^{66}$, is surely a matter of judgment given to the Board, if not a matter of taste. At the worst the Board is entitled to an open verdict in the name of curial deference, not condemnation in the form of a finding of patent unreasonableness.

Madam Justice L'Heureux-Dubé charges the Board with writing a «mini-Code ${ }^{67}$ to fill a perceived void in the Labour Code. With respect, given this judicial concept of mini-Code, the Board would have perpetrated that deed either way. The Labour Code is not a comprehensive code, as is recognized in the judgments ${ }^{68}$. It is a construct for a continuing experiment in "antagonistic cooperation". It is, with respect, farfetched to conclude that the absence of reference to section 27 in the Board's decision justifies the conclusion that the Board overlooked the section.

In fleshing out the language of section 27(1) Madam Justice L'Heureux-Dube notes the three classic employee freedoms which justify the intervention of the state to secure a collective bargaining system as public policy: the rights to organize, to bargain with the employer, and to invoke potentially effective economic sanctions ${ }^{69}$. That is a good beginning. But it neglects the claim of the employer to manage, the claim of «the public» to the delivery of goods and services, and the right and duty of the government to govern ${ }^{70}$. Section 27(1) must be read in the light of those realities. 
The judgment also dwells on the policy of the balance of bargaining power (addressed below) in respect of which the Labour Code implicitly prescribes for the union a «countervailing sanction of proportionate impact ${ }^{71}$. Her ladyship concludes that the Board's decision finds the employer not detrimentally affected. Madam Justice Wilson's postulation of a balance of power inducing compromise relates. That overlooks the political realities of collective bargaining. Solomon threatened to cut the baby in two as a stratagem for identifying the birth mother. The ultimate decision was anything but a compromise. An employer will not compromise if it doesn't have to. Nor will a union. I leave the reader with four examples. In 1950 the firemen's union on the Canadian railways stonewalled at the bargaining table the resolution of the issue of their redundancy resulting from conversion from coal to diesel fuel and initiated a pattern, continuing to this day, of $a d$ hoc legislation imposing binding arbitration on a system of free collective bargaining ${ }^{72}$. In the 1950's in Vancouver, the bakery workers' union insisted that small bakeries, many of them family enterprises, sign the same terms that the union negotiated with the Big Four bakeries (including McGavin), and thereby put the small bakeries out of business $^{73}$. In 1981 President Reagan broke the air traffic controllers' union by bringing in replacement workers. In more recent days Canada Trustco offered a certified union exactly the same terms of employment as applied to non-unionized employees. The organized employees were left with the terms they had at the beginning, plus the obligation to pay union dues ${ }^{74}$.

The foregoing judicial prescription on compromise also runs into trouble with "concession bargaining» which came upon the scene in the economic recession of the early 1980's and was a major cause of the breakaway of the Canadian Auto Workers in that decade: the American union was obliged to accede to the employers' demand for concessions, but the Canadian branch had no reason to do so. Concession bargaining is well illustrated by the introduction of two-tiered wage scales ${ }^{75}$ in the US airline industry with deregulation of the industry and the resulting rise in competition. Concession bargaining was a buzz word during the 1980's. Its flip side may be found in the late 1960's and 1970's when Canada faced double digit inflation and unions demanded and won settlements that compensated not only for inflation from the time of negotiating the expired collective agreement but also for expected inflation during the term of the agreement under negotiation ${ }^{76}$. The result was the anti-inflation wage control legislation of 1975 and the capped wage increases in the public service in the early 1980's. Both events went a long way to changing the character of collective bargaining and the public image of the labour movement. Compromise is a hypothetical standard or norm against which deviations may be observed in the realpolitik of labour-management relations: in a given case there may be no compromise at all.

Would that the directive to the Board in section 27 could be so simple as to leave the Board «no choice» ${ }^{77}$ and thereby render the choice it did make patently unreasonable.

As part of the package of reasons leading to the conclusion that the decision of the Board was patently unreasonable, Madam Justice 
L'Heureux-Dubé, as noted, faulted the Board for not holding policy hearings under section 35 of the Code and issuing guidelines under section 27(1) and (3). The exercise of these powers in the Board is one of the characteristics of the labour code that sets an administrative tribunal apart from the courts. It is clearly discretionary. The Board had before it the British Columbia Labour Code, including section 27, and the terms of the collective agreement which provided for termination of collective bargaining on notice, subject always to the duty to bargain in good faith; the parties were represented by experienced counsel from a sophisticated labour bar; and the proceedings constituted a rehearing before a panel of the Board consisting of the chairman and four vice-chairmen. The arbitrator in Hydro, the appeal from whose decision was part of the case before the Board, was a former chairman of the Board with more than a decade of experience in that field. Are we to conclude that had the Board held policy hearings on the issue of the power of the employer to make unilateral change in the circumstances before the Board, it would have concluded that it had «no choice» but to follow the maverick decision in Cariboo College $e^{78}$ and would thereby have avoided reaching a patently unreasonable conclusion?

\section{ARTIFICIAL DUALITIES IN CANADIAN LABOUR CODES: THE POLITICS OF DRAFTING vS THE REALITIES OF BEHAVIOUR}

Canadian labour codes contain a number of provisions, or seem occasionally to rest on concepts, that appear to treat labour and management evenhandedly, even though organized labour and enterprise are as different as chalk and cheese. I wish to address four artificial dualities as having particular relevance to the themes of this essay: (1) balance of bargaining power; (2) the right to join unions and employers' associations; (3) the duty to bargain in good faith and make every reasonable effort to reach a collective agreement; and (4) the right to strike and to lock out.

\section{Balance of Bargaining Power}

I think it is safe to say that the bargaining power within the dynamics of the statutory scheme is never really in balance. It is like the Big Kid and the Little Kid on either end of the teeter-totter. The «balance» depends on the location of the fulcrum or on the location of the Kids, and on whose feet are on the ground and how hard she/he is kicking, and who is out for a ride or is out to win. The distance from the Kid to the fulcrum is the measure of the concession that that Kid must make to achieve a balance. And it is the legislative control over the location of the fulcrum that helps to preserve the semblance of equilibrium by providing controls such as the duty to bargain in good faith, the prohibition against the use of unfair labour practices, and postponement of the use of economic sanctions. When those controls are removed, in most Canadian jurisdictions when statutory provisions for third party intervention are exhausted and the parties recover the right to strike and lock out, the imbalances that inhere in any labour-management relationship take over. Even then the realities of bargaining power can be 
and are affected by such factors as the duration of a work stoppage, the season of the year, the stage of the business cycle, the general condition of the economy, the threat of ad hoc legislation and, in some cases, the condition of public opinion.

The dissenting judgments in Paccar appear to me to be preoccupied with what really is, again, a conceptual norm against which deviations can be observed in the dynamics of collective bargaining. The concept of «balance» in the judgments contributes to the conclusion that the decision of the Board was «patently unreasonable» for the reason that it releases the employer from restraints on entrepreneurial action after the collective agreement has terminated, after substantial negotiations (on the pleadings there is no question of any breach of the duty to bargain in good faith), and after negotiations have been terminated pursuant to an express provision in the collective agreement but before the employer has acquired the right to lock out, a right, as we shall see, of only peripheral interest to the employer.

\section{Freedom of Association}

The principles of the Canadian labour codes were derived principally from the US National Labor Relations Act of 1934, a Canadian order-incouncil of 1944 and experience under it, and conventions of the International Labour Organization. Labour relations governing about $95 \%$ of the Canadian labour force fall within provincial legislative competence. (The federal jurisdiction sometimes may appear to be bigger than it is because it extends over much of the service sector of the economy where «the public» is sometimes perceived as being used as leverage in trying to shift the fulcrum in the balance of bargaining power, and that makes news.)

In 1947 there was introduced into the House of Commons a draft bill to enact what I have called heretofore, for the sake of simplicity, a labour code. (As pointed out in several judgments in Paccar there is no magic in the term code ${ }^{79}$. The statutes are not complete codifications of the law of collective bargaining and were never intended to be: they deliberately confer discretionary power on the labour boards and they contain latent ambiguities and «lacunae $\rangle^{80}$ that must be resolved and filled by invoking what I call the «mind set» of the common law.) The bill was then tabled for a year to give the provinces time to consider its contents as a model for the exercise of provincial authority. Its influence was to become evident in every province but Prince Edward Island, which clung to British precedents of the 19th century that had little relevance to the post-war Canadian scene and even less relevance to its agricultural economy.

Canada had had experience with a comprehensive collective bargaining scheme only since February 1944, when a federal order-in-council was passed to regulate collective bargaining in a wartime economy. When the time came to draft a comprehensive collective bargaining statute, the policy makers recognized that it was necessary to protect, as against the employer, the right of employees to organize themselves into trade unions. So the bill contained a clause declaring that every person is free to join a trade union of his own choice and to participate in its lawful activities ${ }^{81}$. True to the 
mythology of even-handedness and thus treating unlike things alike (a short route to injustice), the provision was followed by a clause declaring that every person is free to join an employers' association of his choice. It is not clear against whom that declaration is directed, but, playing the game of quid pro quo, trade unions might be identified as the object. In any event, the problem was not that employers were being prevented from joining employers' associations but that they were not prevented from leaving them. It is a real challenge to the spirit of free enterprise that employers in competition with one another should limit their freedom by binding themselves to collective action. At that time employers' associations were well known, and employer members were known to wander away from collective understandings and make a deal with the union. They were also known to make a deal with the union that in the event of a strike in the industry the union would leave the employer alone on an undertaking that at the end of the strike it would meet the terms of the settlement, usually retroactively. The quid pro quo section for employers' organizations was, well, convenient. It was not until some two decades later that labour codes were amended to introduce a scheme of «accreditation» of employer associations in the construction industry ${ }^{82}$, which locked employers into the association and committed them to the substantive results of collective bargaining, that the real problem relating to employer associations was effectively addressed ${ }^{83}$.

\section{The Duty to Bargain in Good Faith}

The duty to bargain in good faith and make every reasonable effort to make (reach) a collective agreement is imposed on the union and the employer even-handedly. It is akin to the prohibition against the rich and the poor alike to sleep under the bridges of Paris ${ }^{84}$. In a scheme of collective bargaining that postpones the right to strike the union is dead in the water if it cannot bring the employer to the bargaining table.

The real effectiveness of the duty to bargain in good faith is its impact on the employer, not its even-handed application to the employer and the union. The labour board jurisprudence under the labour codes bears that out $^{85}$.

The statutory duty also is the fundamental provision of the labour codes that renders the common law of contract irrelevant to the creation and administration of the collective agreement, and to the relationship between the employer and the employee (see above).

\section{The Right to Strike and to Lock Out}

Having demonstrated, I trust, that the Canadian labour codes contain false equivalences the unmasking of which is of considerable importance, I now turn to the one of particular relevance to Paccar.

When it comes to the exercise of economic sanctions in the resolution of labour-management disputes, the employer's «equivalent» of the union's 
right to strike is not the right to lock out: it is the power to take a strike, to stay in operation. Basically, the only time when an employer will lock out its employees is when it faces a worse alternative, such as whipsawing (in which the union picks on one employer in an industry while the other employers continue to operate, and reaches an agreement which the union uses as a precedent for settlement across-the-board). That is what brings employers into employers' associations, an otherwise unnatural act in a free market economy. Apart from that the employer will stockpile its product to last out a strike. It will shift production to other plants, or make a deal with a friendly competitor to fill its customers' orders. And it will hire «replacement workers». But it will not lock out. The code puts restraints on these activities. And the union has countervailing recourse to picketing and boycotting, which also come under the surveillance of the codes and/or the common law.

In the Supreme Court of Canada counsel for the respondent argued his case on the basis of the duality of the strike and the lockout, putting the case that releasing the employer from restraints against taking action of economic significance for which the union had no countervailing power, the right to strike and to lock out not having ripened, was a violation of the principle of duality or equivalence and countervalence of bargaining power that underlies the labour code. An examination of the respondent's factum makes the line of reasoning quite clear ${ }^{86}$. It is submitted that the dissenting judgments misapprehend the real duality as well as the nature of the «balance» of bargaining power.

\section{THE NATURE AND APPLICATION OF THE STANDARD OF REASONABLENESS}

In the ordinary case reasonableness is a legal standard that is applied to directly provable facts of events and relationships in order to reach a conclusion of derivative «purpose-oriented» fact ${ }^{87}$. The standard is often stated in the anthropomorphized form of the «reasonable man». In reality the reasonable person is none other than the judge her/him/self, who puts the reasonable person forward to objectivize, or depersonalize, the application of the standard in a particular case.

The question of judicial review of statutory tribunals - for present purposes the labour boards and labour arbitrators - has been a sensitive area in labour law since the enactment of the postwar labour codes and provisions in them designed to put restraints on judicial review and the quashing (or otherwise) of decisions on grounds of jurisdictional error of one kind or another. In 1979 the Supreme Court of Canada focused the issue in the concept of "curial deference»: that where a board has statutory jurisdiction to embark on an inquiry the court ought to defer to the expertise of the board even where the board makes an error of law, unless the conclusion reached on the point of law was «patently unreasonable»" ${ }^{88}$. As the Supreme Court of Canada reminds us in Paccar, that test is a severe one $^{89}$; and it helps to translate the application of the standard of reasonableness on a question of derivative fact to a question of law. 
Madam Justice Wilson observed, on a point that does not challenge the majority judgments, that

when we postulate the test of patent unreasonableness we are attempting to assess the reasonableness of the Board's decision, not in terms of the reasonable man or reasonable member of the general public, but in terms of the reasonable Board. This must be so if we are to allow for the fact that the Board is deemed to have special expertise. A patently unreasonable decision is accordingly one which no reasonable Board applying its expertise could possibly have arrived at ${ }^{90}$.

I find the observation helpful, even though, for reasons I have already attempted to set out, I think her ladyship reached the wrong conclusion ${ }^{91}$.

Perhaps of greater interest is the question of how a judicial mind should go about applying the standard. The process of reasoning, or the «mind set», propounded by Mr. Justice La Forest and by Mr. Justice Sopinka are subtly but, I think, fundamentally different.

Mr. Justice La Forest states that the first step in determining whether an administrative tribunal has exceeded its jurisdiction by answering a question of law in a patently unreasonable manner is to determine the tribunal's jurisdiction by looking at (a) the wording of the statute, (b) the purposes of the statute, (c) the reason for the existence of the tribunal, (d) the area of expertise of the members, and (e) the nature of the problem before the tribunal ${ }^{92}$. That done, his lordship would ask whether there is a rational basis for the decision, that is, how did the tribunal arrive at the result, not «do I agree with it» ${ }^{93}$. If the judge concludes that the decision is not "patently unreasonable», the judge does not have to determine whether s/he agrees with it. Mr. Justice La Forest found that the decision had a rational basis, and he therefore was in favour of allowing the appeal, without having to reach a conclusion as to whether he agreed with it.

That, I submit, postulates a pretty cool adjudicator.

Mr. Justice Sopinka asserts that the reviewing court cannot avoid forming an opinion on the merits of the decision under review. If the court agrees that the decision is correct, that is the end of the matter. If the court disagrees, it must apply the "severe test» that the decision of the statutory tribunal was "patently unreasonable». If the court concludes no, curial deference dictates that the court not interfere with the decision of the administrative tribunal. If the court concludes yes, the decision must be quashed. Mr Justice Sopinka agreed with the decision, and therefore was in favour of allowing the appeal.

I much prefer the prescription for the «mind set» presented by $\mathrm{Mr}$ Justice Sopinka. I think that's the way I think ${ }^{94}$.

\section{STANDING OF THE INDUSTRIAL RELATIONS COUNCIL}

In 1987, well after Paccar had embarked on its voyage of discovery through the rocks and whirlpools of the Board and the Courts, the British Columbia Labour Code was amended in a number of respects, one of which 
was to change its title to the Industrial Relations Act and to rename the Labour Relations Board the Industrial Relations Council. In the Supreme Court of Canada, on the question of the standing of the tribunal Madam Justice L'Heureux-Dubé uses its statutory title at the time the legal proceedings cast off; Mr. Justice La Forest uses the designation Industrial Relations Council, being appropriate to the time the legal proceedings were finally cast ashore.

The union argued that the Council had no standing before the Supreme Court of Canada to make submissions in support of the reasonableness of its decision.

Mr. Justice La Forest was of the view that the Council had standing (1) to make submissions explaining the record before the court, (2) to show that it had jurisdiction to embark on the inquiry (a point conceded by the union - it was, after all, seeking a remedy from the tribunal), and (3) to show that it had not lost jurisdiction through a patently unreasonable interpretation of its powers.

Mr. Justice La Forest quotes with approval the following passage from the judgment of Mr. Justice Taggart of the British Columbia Court of Appeal in British Columbia Government Employees' Union v. Industrial Relations Council ${ }^{95}$ :

The traditional basis for holding that a tribunal should not appear to defend the correctness of its decision has been the feeling that it is unseemly and inappropriate for it to put itself in that position. But when the issue becomes, as it does in relation to the patently unreasonable test, whether the decision was reasonable, there is a powerful policy reason in favour of permitting the tribunal to make submissions. That is, the tribunal is in the best position to draw the attention of the court to those considerations, rooted in the specialized jurisdiction or expertise of the tribunal, which may render reasonable what would otherwise appear unreasonable to someone not versed in the intricacies of the specialized area. In some cases, the parties to the dispute may not adequately place those considerations before the court, either because the parties do not perceive them or do not regard it as being in their interest to stress them.

Counsel for the Council made two submissions: the British Columbia Court of Appeal erred in reviewing for correctness instead of for reasonableness, a point on which Mr. Justice La Forest agreed; and the Council addressed every submission made to it by the union and rejected each argument with reasons: counsel for the Council did not argue the correctness of the Council's (Board's) decision.

Madam Justice L'Heureux-Dubé agreed that the Board had standing to make arguments relative to the applicable standard of review (clearly a question of law) as well as to the steps it followed in reaching its decision. Neither argument addressed the correctness of the decision.

The issue of standing was not addressed in the judgments of Mr. Justice Sopinka and Madam Justice Wilson. 


\section{WHAT IS THE IMPORTANCE OF PACCAR?}

There are two major limitations to the significance of Paccar in labourmanagement relations in Canada. The first is that it relates only to relationships that fall under the labour codes. It leaves untouched about $65 \%$ of the work force. (What the British Columbia Court of Appeal had to say about the present condition of the common law of the contract of employment may very well be appropriate to that $65 \%$.)

Second, there is much law imposing rights and duties on employees and employers that flows from statutes independent of collective bargaining law and applying across-the-board without regard to the boundaries of the labour $\operatorname{codes}^{96}$. I refer to what commonly is called Employment Law, relating to such matters as occupational health and safety, employment standards, industrial standards and legislation protecting pension funds ${ }^{97}$. Some of the legislation predates modern collective bargaining by generations, such as worker's compensation statutes. Some statutes have come onto the scene in more recent times where collective bargaining has not provided and probably cannot provide a mechanism responsive to need, such as pay equity legislation. Some are pervasive to the social fabric, such as human rights legislation. That is true of the Charter of Rights and Freedoms, but claims under the Charter require that a government presence be found. Collectively, these statutes provide a social safety net of a different dimension from that of collective bargaining.

Paccar, then, relates to a form of social legislation that is designed to bring a form of worker participation into the governance of the work place through a highly regulated system of collective bargaining.

It would be easy to dismiss Paccar for the reason that the British Columbia Labour Code does not speak, or does not speak directly, to the matter of the freeze and the employer's power to alter terms and conditions of employment between impasse and the acquisition of the right to strike and lock out, whereas all the other Canadian labour codes do. It would be facile to dismiss it for the reason that the parties bargained for the power to terminate bargaining over a new collective agreement, even though the duty to bargain in good faith is coterminous with the certification of the union: that fact did not feature in the judgments in the Supreme Court of Canada. And it would be wrong to limit the instructive qualities of the case to the nature, scope and «mind set» of judicial review in the presence of a «stateof-the-art» privative clause, solely because that, strictly, is the bare ratio of the case in the Supreme Court of Canada.

Paccar helps us to clarify a number of questions of a jurisprudential character which reflect on the fundamental nature of collective bargaining in Canada, and its impact on those affected by its operation and how the performers interact. The format of this essay is designed to give easy access to those issues.

1. It is a thesis of this paper that a collective agreement is not a contract: it is a consensual instrument of a different quality: among other things, it is a creature of statute. Because it is a consensual instrument the analogy with contract may be instructive from point to point, but labour boards and 
arbitrators must exercise their discretionary powers in the special medium of regulated collective behaviour. That collective component, then, requires an appreciation of the statutory interrelation of the employer, the union and the employee.

2. The question must be asked what has been the impact of that interrelationship on the legal status of the employee? The employee no longer has the protection, if that is what it ever was, of the contractual masterservant relation at common law ${ }^{98}$. His protection must be sought not on the theory of freedom of contract but on the statutory duty of the employer to bargain in good faith and to honour the collective agreement, and the duty of the union to negotiate and police the collective agreement fairly $v i s-\grave{a}$-vis the employees ${ }^{99}$. The juridical condition of the employee in the context of regulated collective bargaining has unfolded, with progressive intervention by the state, from contract to status.

3. An exploration of a statutory statement of purposes and objects must begin with an understanding of competing interests in a scheme of collective bargaining. The freedoms that are associated historically with the effective US experiment in $1934^{100}$ are the freedom of employees to combine, to bargain with the employer and to invoke potentially effective economic sanctions. There are three other interests that claim attention: the employer's freedom of entrepreneurial action, the claim of 'the public' to the delivery of goods and services, and the right and duty of governments to govern. The interpretation of a statutory statement of purposes and objects cannot be pursued with a singleness of purpose; much depends on circumstances and one's perception of them. Interests, like freedoms, are not absolute: they cannot be, and coexist.

4. Related to the subtleties involved in the interpretation of 'purposes and objects' clauses is the matter of what I call the artificial dualities in the codes that simply do not reflect accurately the dissimilarities of values of the parties and disparities in strategies and practices: Paccar offers a lesson.

5. Paccar presents a neat exercise in determining the true ratio of the decision of the Supreme Court of Canada. It offers once again the emerging condition of the law respecting judicial review and curial deference to decisions of specialized statutory tribunals. Mr. Justice La Forest (Chief Justice Dickson concurring) found that the reasoning by which the Board arrived at its conclusion of law was rationally defensible and therefore by the doctrine of curial deference his lordship did not have to form an opinion as to whether it was right. Mr. Justice Sopinka (Mr. Justice Lamer concurring) found that the Board's conclusion of law was right and therefore the exercise in judicial review was at an end and the issue of curial deference did not arise. Madam Justice Wilson and Madam Justice L'Heureux-Dubé found that the conclusion reached by the Board was patently unreasonable and therefore fell outside the protection of curial deference (and hence outside the protection of the privative clause).

Paccar should not be assessed as being anomalous. It should be studied for the insights it can offer into the nature of the judicial process and ways of judicial thinking, and into what informs - gives shape to - one's judgment. 
The clue to the economic, social and political significance of Paccar to trade unions throughout Canada is the golden thread of the employer's continuing duty, so long as the union's certificate of exclusive bargaining authority prevails, to bargain in good faith and to harbour the intention to enter into a collective agreement. In Paccar the door to the bargaining table never closed; and the employer did unilaterally no more than he sought by bargain.

Whatever evidentiary problems may be presented in making a factual determination as to whether and in what circumstances a party's behaviour amounts to a breach of that duty, that may now be perceived to be the focus of this kind of case, not a revived contract of employment. I should have thought that this gain to the union at the point of impasse was palpably more important than the sacrifice of the time it took in British Columbia for a union to recover the right to strike, a sacrifice that does not relate in other Canadian jurisdictions.

\section{NOTES}

1 [1989] 2 S.C.R. 983.

2 Actually, it was taken from a US Strike Commission Report of 1895 , but its merits were not appreciated in that country for another 30 years: see A.W.R. CARROTHERS, E.E. PALMER and W.B. RAYNER, «Controlling the Use of Economic Sanctions: The Assertion of the Public Interest in Resolving Industrial Conflict (1900-1932)», Collective Bargaining Law in Canada, 2nd ed., Toronto, Butterworths, 1986, pp. $35 \mathrm{ff}$. See esp. Industrial Disputes Investigation Act, 1907, S.C. c. 20.

3 The statutory freeze provisions are collected in the judgment of La Forest J., p. 1011.

4 British Columbia: Industrial Relations Act, R.S.B.C. 1979, c. 212, ss. 70-72, rep. 1987, c. 24, s. 37. See also Manitoba: Labor Relations Act, R.S.M. 1987, c. L-10, s. 87; Ontario: Labour Relations Act, R.S.O. 1980, c. 228, s. 40 (a); Québec: Labour Code, R.S.Q. 1977, c. C-27, ss. 93.1-93.9.

5 Canadian Association of Industrial, Mechanical and Allied Workers.

6 Note the fictional duality, reviewed at length below.

7 Briefly, a dependent contractor is a person who looks like an employee, walks like an employee, and quacks like a self-employed person (an independent contractor). The labour codes treat him as an employee; some codes require, and some permit, him to be in a separate bargaining unit: see Michael BENDEL, «The Dependent Contractor», (1982) 32 U of TLJ 374.

8 Chairman Donald R. Munroe, former chairman of the B.C. Labour Relations Board.

9 Chairman Kinzie. BC LRB decision No 284/85 (Appeal of No. 291/84) 2 Oct. 85.

10 McGavin Toastmaster Ltd. v. Ainscough, [1976] 1 S.C.R. 718.

1111 June 1984 , p. 7.

12 Id., p. 27.

13 Id., p. 31.

14 There is nothing in the record to indicate any such agreement. The employer's written notice quoted above refutes the finding. 
15 Nemetz CJBC and Esson, Hinkson, Hutcheon and Seaton JJA.

16 (1986) 7 B.C.L.R. (2d) 80, p. 83.

17 Id., paraphrase of pp. 84-85.

18 Id., p. 86.

19 McIntyre J. heard the appeal but retired before the appeal was decided and took no part in the judgment.

20 Supra, note 1, p. 1005.

21 Id., p. 1008.

22 Id., p. 1019.

23 Ibid.

24 Id., p. 1020.

$25 \quad I d .$, p. 1023.

$26 \quad I d .$, p. 1024.

27 Ibid.

28 Id., p. 1024, citing the British Columbia Court of Appeal.

29 Ibid.

30 Id., p. 1025.

$31 \quad I d .$, pp. 1032, 1042.

$32 \quad I d .$, p. 1032.

33 This is tendered as an encapsulation of pages 1033-1044, «II Infringement Upon the Fundamental Objectives».

34 Supra, note 1, p. 1044.

35 Id., p. 1043.

36 Supra, note 16, p. 83.

37 Id., p. 84.

38 Ibid.

39 Ibid.

40 N.A. Citrine, Citrine's Trade Union Law, 3d ed. by M.A. Hickling, London, Stevens, 1967, 722 p.; Lord WedDerBuRn, The Worker and the Law (3d ed.), Harmondsworth, Penguin Books, 1986, 1026 p.

41 E.g. Young v. Canadian Northern Railway, (1931) 1 D.L.R. 645 (P.C.). See Bernard AdELL, The Legal Status of Collective Agreements in England, The United States and Canada, Kingston, Industrial Relations Centre, Queen's University, 1970.

42 See George W. Adams, Canadian Labour Law - A Comprehensive Text, Aurora, Ont., Canada Law Book Inc., 1985, 983 pp., pp. 579-580.

43 Ibid., p. 575.

44 E.g. National Bank of Canada v, Retail Clerks' International Union, [1984] 1 S.C.R. 269 in which the remedy was quashed, and Slaight Communications Inc. v. Davidson, [1989] 1 S.C.R. 1038; 59 D.L.R. (4th) 416 (S.C.C.) in which the remedy was sustained. In each case the tribunal set out to devise a remedy that would take from the employer any benefit from its wrongdoing. One strategem passed muster, the other did not.

45 The jurisprudence of labour arbitration runs to over ten feet of shelf space in Labour Arbitration Cases and the cases are analyzed in two excellent treatises: D.J.M. BRown and D.M. BeATTy, Canadian Labour Arbitration, (3d ed.) Aurora, Ont., Canada Law Book Inc., 1988, E.E. Palmer, Collective Agreement Arbitration in Canada, (2d ed.) Toronto, Butterworths, 1983, 905 pp., (supplement). See also Howard LEvitT, Law of Dismissal in Canada, Aurora, Ont., Canada Law Book Inc., 1985, 358 pp., David Harris, Wrongful Dismissal, Don Mills, Ont., Richard de Boo, (looseleaf, current), Ellen E. Mole, Wrongful Dismissal Practice Manual, Scarborough, Ont., Butterworths, 1989.

46 The Provincial Arbitration Acts, designed in 1889 to legitimize commercial arbitration and reverse the decision of the House of Lords in Scott v. Avery (1856), 5 HL Cas. 811, which held otherwise, have long since been removed from labour arbitration in Canada to make way for the prescription of arbitral powers in the labour codes. 
47 Supra, note 10, pp. 724-725.

48 F.R. BATt, The Law of Master and Servant, $4^{\text {th }}$ ed. by Crossley Vaine, London, Pitman, $1951,520 \mathrm{pp}$.

49 At the moment of writing the point is moot. By way of example see Trafford $v$. Treasury Board, PSSRB file 166-2-14366 (Roger Young) 17 Sept. 1985. The debate involved an issue of statute interpretation as well as the distinction between correcting a mistake (form) and changing a term (substance).

so Rose \& Frank Co. v. JR Crompton \& Bros. Ltd., (1925) A.C. 445 (H.L.).

s1 British Columbia was one of the first jurisdictions to experiment with first agreement arbitration. The section was repealed in 1987, effective in 1988 (supra, note 4).

52 Courts and Boards.

53 Supra, note 10, pp. 724-725.

54 (1976) 12 L.A.C. 337 cited in his 1984 decision, p. 7.

s5 Telegram Publishing Co. Ltd. v. Zwelling et al. (1976), 67 D.L.R. (3d) 404 (Ont. C.A.).

56 Id., p. 412.

57 The decision of the second panel of the Board reads in part:

It has been suggested that only those which are related directly to the employeremployee relationship should be implied and not those that relate to the employer-union relationship. This issue was not argued before us in this proceeding. We mention this point only to make it clear that we are making no decision at this time on this issue.

58 Supra, note 1, p. 1009 (La Forest J.).

59 Id., p. 1094 (L'Heureux-Dubé J. citing B.C.C.A.).

60 See the strategy of counsel for the union in the Supreme Court of Canada as evidenced in the dissenting judgments. Counsel's argument to the same effect is recorded in the second hearing of the BCLRB: supra, note 9, p. 10.

61 The present form of section 27 is set out below. I think my point is made without taking the reader back to its antecedent.

Sec. 27 (1) The Council, having regard to the public interest as well as the rights of individuals and the rights and obligation of the parties before it and recognizing the desirability for employers and employees to achieve and maintain good working conditions as participants in and beneficiaries of a competitive market economy, shall exercise the powers and perform the duties conferred or imposed on it under this Act so as to achieve the expeditious resolution of labour disputes, and for these purposes the council shall have regard to the following purposes and objects:

(a) securing and maintaining industrial peace and furthering harmonious relations between employers and employees;

(b) improving the practices and procedures of collective bargaining between employers and trade unions as the freely chosen representatives of employees;

(c) promoting conditions favourable to the orderly and constructive settlement of disputes between employers and employees or their freely chosen trade unions;

(d) encouraging the voluntary resolution of collective bargaining disputes;

(e) minimizing the harmful effects of labour disputes on persons who are not involved in the disputes;

(f) providing such assistance to employers and bargaining agents as may facilitate the making or renewing of collective agreements;

(g) gathering and publishing information and statistics respecting collective bargaining in the Province.

(2) The council may formulate general guidelines to further the operation of this Act; but the council is not bound by those guidelines in the exercise of those powers or the performance of its duties. 
(3) In formulating general guidelines the council may request that submissions be made to it by any person.

(4) The council shall make available in writing for publication all general guidelines formulated under this section, and their amendments and revisions.

62 See George W. Adams, supra, note 42, Chapter 10 «Unfair Labour Practice Proceedings", pp. 481-615; CARrothers, PALMER and RAYNer, supra, note 2, pp. 269-314 and 447-456.

63 Ibid.

64 Supra, note 1, pp. 1027-1028.

65 Id., p. 1032.

66 Section 27(2), supra, note 61.

67 Supra, note 1, p. 1032.

68 Id., p. 1019 (Sopinka J.).

69 Id., p. 1033.

70 A.W.R. CARrothers, «A Way of Thinking about Collective Bargaining», (1985) 40 Relations Industrielles 351-366.

71 Supra, note 1, p. 1035.

72 At the time of writing (December 1989) parliament legislated the return to work of federal ships' crews and hospital workers, coupled with binding arbitration.

73 Later the Vancouver bakeries were to supply their British Columbia customers overthe-road from Calgary. Such is the nature of market forces in a collective bargaining environment.

74 Canadian Union of United Brewery etc. Workers (complainant) v. Canada Trustco Mortgage Co. (respondent) [1984], OLRB Rep. 1356 (MacDowell V-C).

75 Collective agreements provided that current salary scales be maintained for present employees (tier one) but that reduced salary scales be applicable to new employees (tier two) in an unregulated industry. The potential for discord within the bargaining unit was enormous. Tiers, idle tiers...

76 The inflation that hit Canada in the mid 1960's and was to continue for a decade started in the United States when President Johnson determined in the election year 1964 not to raise taxes to pay for the Vietnam War and to resort to deficit financing. In 1965-66 the employees on the Canadian side of the new (1959) St. Lawrence Seaway demanded «wage parity» with employees on the United States side (dollar figure for dollar figure, without regard to exchange rates or comparative purchasing power). Under threat of a strike Prime Minister Pearson accepted the advice that a strike would be avoided with a $30 \%$ increase in wage scales. That settlement upset negotiations on the railways. The resulting railway strike was terminated by ad hoc legislation ordering a return to work and the imposition of binding arbitration. That action led to the appointment of a Task Force on Labour Relations which made a comprehensive review of labour relations in Canada. Reflections upon its report (1969) led to amendments to the federal collective bargaining statute in 1973.

77 Supra, note 1, p. 1019.

78 Cariboo College and Cariboo College Faculty Association (1983), 4 CLRBR (NS) 320.

79 Supra, note 1, p. 1019 (Sopinka J.).

80 Ibid.

81 This provision was misconstrued in CSAO National v. Oakville Trafalgar Memorial Hospital Association and OLRB (1972), 72 CLLC para 14,118 (Ont. CA) in spite of the S.C.C. judgment in C.P.R. Co. v. Zambri (1962), 34 D.L.R. (2d) 654 (Cartwright J.).

82 Report of the Royal Commission on Labour-Management Relations in the Construction Industry, (Carl H. GoldenberG, Commissioner, Toronto, QP, 1962. See also Carl H. Goldenberg and John CRIspo, Construction Labour Relations, Canadian Construction Association, Ottawa, 1968, $763 \mathrm{p}$. 
83 In economic terms the solution continues to be wobbly: e.g. should settlements in the construction industry reached for the Greater Toronto area, with its unique labour market characteristics, be accepted as a precedent for the industry in the «hinterland»? Does not the answer require consideration of different balances of bargaining power, different equilibria?

84 Anatole FranCE, 1894.

85 E.g. George W. AdAms, supra, note 42; G. SACK and M. Levinson, Ontario Labour Relations Board Practice, Toronto, Butterworths, 1973, 552 p. and suppl. 1977.

86 Supra, note 60.

87 As distinct from a statement of an event (lightning struck) or a statement of a relationship $(2+2=4)$. A statement of intent or purpose or quality must be derived (hence «derivative fact» from provable evidence of events and relationships.

88 Canadian Union of Public Employees Local 963 v. New Brunswick Liquor Corp., [1979] 2 S.C.R. 227, per Dickson J. Seee also McIntyre J. in Reference Re Public Service Employee Relations Act (Alta.), [1987] 1 S.C.R. 313 et pp. 416, cited by La Forest, J., in Paccar. See also George W. ADAMs, supra, note 42, p. 159 ff, esp. pp. 172-186. And see Brian Etherington, "Arbitration, Labour Boards and the Courts in the 1980's; Romance Meets Realism", (1989) 68 Can. Bar Rev. 405.

89 Supra, note 1, p. 1003 (La Forest J.).

$90 I d .$, p. 1021. The use of the work «possibly» reflects the strictness of the test of patent unreasonableness. To me it reflects the strength of her ladyship's conviction that the decision of the Board was patently unreasonable.

91 Of the four written judgments in Paccar, one finds the Board's decision to be reasonable (I prefer to say that it falls within the range of reasonableness), one finds the Board's decision to be correct, and two find the decision to be patently unreasonable. Are we hearing the four fully human and alive members of the Supreme Court of Canada or a screened rendition of the standard of reasonableness?

92 See U.E.S., Local 298 v. Bibeault, [1988] 2 S.C.R. 1048, p. 1088.

93 Supra, note 1, p. 1005.

94 I don't think I can keep from my mind the question whether I agree with the decision while I ponder the question whether the decision had a rational basis. Would I not test the rationality of the basis of the decision by asking whether I agree with it and then, if I find I disagree, ask whether the decision is nevertheless rational? Would not anyone charged with determining the rationality of a decision pass it at some point through the screen of one's own judgment on the merits?

95 Unreported, BCCA, 24 May 1988. Cited by La Forest J., p. 1016.

96 See B. REITER, «The Control of Contract Power» (1981), 1 Oxford J. of Legal Studies 347, at 350-51, cited in Labour Law: Cases, Materials and Commentary (4th ed. 1986), published by Queen's University.

97 E.g. Innis Christie, Employment Law in Canada, Toronto, Butterworths, 1980, 518 p., C. Bentley, J. McNair \& M. Butkus, The Annotated Ontario Employment Law Statutes, Toronto, Carswell, 1989.

98 The master-apprentice relationship was a domestic one: a status relationship. See generally, F.R. BATT on Master and Servant, supra, note 48.

99 See G.W. Adams, supra, note 42, Ch. 13: «Duty of Fair Representation», pp. 710-769.

100 The National Labor Relations (Wagner) Act, 1935, 40 Stat. 449 (US). 